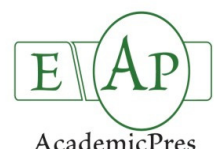

\title{
Influence of Biodynamic Preparations on the Quality Indices and Antioxidant Compounds Content in the Tubers of Coloured Potatoes (Solanum tuberosum L.)
}

\author{
Elvyra JARIENE $\dot{1}^{1}$, Nijolè VAITKEVIČIENË $\dot{E}^{1 *}$, Honorata DANILČENKO ${ }^{1}$, \\ Marek GAJEWSKI ${ }^{2}$, Galina CHUPAKHINA ${ }^{3}$, Pavel FEDURAJEV ${ }^{3}$, Reto INGOLD ${ }^{4}$ \\ 1AleksandrasStulginskis University, Studentustr.11,Akademija,LT-53361Kauno district,_Lithuania; elvyra.jariene@asu.lt;nijolevaitkeviciene2@gmail.com \\ (*correspondingauthor); honorata.danilcenko@asu.lt \\ ${ }^{2}$ Warsaw University of Life Sciences - SGGW, Nowoursynowska 166,02-787Warszawa, Poland; marek_gajewski@sggw.pl \\ 3Immanuel Kant Baltic Federal University, Universitetskaya2,236041 Kaliningrad,Russia; tchoupakbina@mail.ru;pavelf15@mail.ru \\ ${ }^{4}$ Ecology and Innovation, Training and consultingfor biodynamicfarming, In Zelg4, CH-4144 Arlesheim, Switzerland; reto.ingold@demeter.net
}

\begin{abstract}
Biodynamic preparations 500 and 501 are plant strengthening agents of biodynamic agriculture method, prepared of manure and powdered quartz. The objective of the present study was to determine effects of biodynamic (BD) preparations 500 and 501 on the quality indices and antioxidant compounds content in the tubers of coloured flesh potatoes. The experiment included two factors: potato cultivar and treatment with BD preparations as field sprays. The experiment was carried out in four replications, in a randomly design. Results showed that application of BD preparations did not influence significantly the contents of dry matter, crude fibre and crude ash in all tested cultivars. Separately used BD preparation 500 increased content of total anthocyanins in tubers of 'Vitelotte' and 'Red Emmalie' and leucoanthocyanins content in 'Blue Congo', but decreased the content of total phenolics in all cultivars. Treatment with BD preparation 501 had significant effect on the contents of total phenolics and total anthocyanins in all cultivars. However, treatment with BD preparation 500 in combination with BD preparation 501 substantially increased the contents of total phenolics and total anthocyanins in all cultivars. Tubers of 'Vitelotte' with dark-purple flesh contained significantly more antioxidant compounds than the lightpurple and red.
\end{abstract}

Keywords: coloured potato cultivars, biodynamic agriculture, crude fiber, crude ash, anthocyanins, phenolics

\section{Introduction}

Potato is one of the most widely grown vegetables and represents an important source of nutrients in many countries (Leo et al., 2008). It is a balanced food containing high energy, nutritional quality proteins, dietary fibre and minerals (Pęksa $e t$ al., 2013; Danilčenko et al., 2014). In current years, more attention is being given to the research of red and purple coloured potato cultivars, due to their antioxidant property, which is related to various polyphenols (Nayak et al., 2011; Jariene et al., 2013). There are number of studies showing that these antioxidants of high free radical scavenging activity may reduce the risk of chronic health diseases and age related neuronal degeneration (Teow et al., 2007; Dai and Mumper, 2010; Khurana et al., 2013).
There are number of reports on the negative effects of using chemicals in agriculture on the quality of vegetables and fruits (Lairon, 2010).

Therefore, in order to preserve the quality of potatoes it is necessary to look for alternative farming methods like biodynamic agriculture. Similar to traditional organic agriculture, biodynamic agriculture eliminates synthetic chemical fertilizers and pesticides. A major difference is that biodynamic farmers use eight specific preparations (Zaller and Kopke, 2004). Biodynamic (hereinafter BD) preparations are plant strengthening agents and they belong to two classes: preparations sprayed directly onto the soil or crops (500 and 501) and preparations added to composting farmyard manure (502-507). The main aim of these preparations is to improve soil and plants quality (Reganold, 1995; Raupp, 1999; Koepf et al., 2001).

Received: 23 Oct 2014. Received in revised form: 07 Nov 2015. Accepted: 19 Nov 2015. Published online: 10 Dec 2015. 
Table 1. Description of potato cultivars

\begin{tabular}{lccc}
\hline Cultivar & 'Vitelotte' & 'Blue Congo' & 'RedEmmalie' \\
\hline Time of maturity & Medium later & Medium early & Medium early \\
Colour of flesh & Dark purple & Light purple & Red \\
Colour of skin & Dark purple & Dark purple & Red \\
Shape of tuber & Long & Round & Long \\
Depth of eyes & Deep & Shallow & Shallow \\
\hline
\end{tabular}

The BD preparation 500 is made from high quality manure, fresh or aged, put in bovine horns, then buried at autumn and dug up in spring, after that it can be stored under controlled conditions for some months. The resulting product is dissolved in water and sprayed on the soil (Brinton, 1997). The other field spray is one made of silicon dioxide and is known as $\mathrm{BD}$ preparation 501. It is used to reinforce the plant against pests and diseases and to improve its nutritional properties, flavours and shelf-life. A very small quantity of the 501 is then dissolved in water and sprayed on the plans, mostly at flowering stage (Koepf et al., 2001; Catellani, 2006). These two BD preparations are believed to work synergistically, with BD preparation 500 mainly improving the common soil fertility, and BD preparation 501 being active in enhancing the plant physiological response to the light radiation (Spaccini et al., 2012).

According to some authors the products of biodynamic agriculture are nutritionally superior and they taste better than the conventional foods (Fritz and Kopke, 2000; Jayasree and Annamma, 2006). However, studies on the impact of BP preparations on the potato tuber quality indices are very limited. Therefore, the aim of this study was to establish effects of $\mathrm{BD}$ preparations 500 and 501 on some quality traits and antioxidant compounds content in the tubers of coloured potatoes.

\section{Materials and Methods}

\section{Growth conditions and plant material}

Field experiment was carried out in 2013-2014 in organic farm (Prienai district, Lithuania). When using BD preparations, potatoes were grown applying the traditional potato growing technology (Ražukas, 2003). The tubers were planted in May, and harvested in September. The field experiment was carried out in four replications, arranged randomly. The overall field size of experiment was $17.5 \mathrm{~m}^{2}$, whereas the size of the accounting field was $10 \mathrm{~m}^{2}$. The main soil properties were as follows: soil $\mathrm{pH}$ Ka $6.86-6.92$, content of total nitrogen $0.126-0.142 \%$, available phosphorus $166.1-181.8 \mathrm{mg} \mathrm{kg}^{-1}$ and available potassium $207.6-248.8 \mathrm{mg} \mathrm{kg}^{-1}$.

The experiment included two factors: potato cultivar ('Vitelotte', 'Blue Congo' and 'Red Emmalie', with the characteristics presented in Table 1) and treatment with $\mathrm{BD}$ preparations as field sprays. There were four treatments to evaluate the effectiveness of BD preparations:

1. Control (BD preparations were not used).

2. $\mathrm{BD}$ preparation 500 (the soil was sprayed two weeks before the planting of tubers, $1 \%$ solution).

3. $\mathrm{BD}$ preparation 501 (two times early in the morning potato plant leaves were sprayed with $0.5 \%$ solution, in the VIII and IX stages of organogenesis).

4. $\mathrm{BD}$ preparation 500 in combination with $\mathrm{BD}$ preparation 501 (two weeks before the planting of the tubers the soil was sprayed with $\mathrm{BD}$ preparation 500 with $1 \%$ solution, and two times early in the morning potato leaves were sprayed with BD preparation 501 with $0.5 \%$ solution in the VIII and IX stages of organogenesis).
$\mathrm{BD}$ preparations 500 and 501 were purchased in the Biodynamic Preparations Centre, Germany.

\section{Chemical analyses}

Chemical potato tubers analyses were conducted in the Laboratory of Food Raw Materials, Agronomic and Zootechnical Investigation of Aleksandras Stulginskis University and in the laboratory of Immanuel Kant Baltic Federal University (Kaliningrad, Russia). Each laboratory sample comprised $5 \mathrm{~kg}$ of tubers.

\section{Dry matter, crudefibre and crude ash analyses}

Dry matter in the tubers was determined by drying samples at temperature of $105{ }^{\circ} \mathrm{C}$ to the constant weight (LST ISO 751:2000); content of crude fibre was determined by the method of Heneberg-Shtoman (Methodenbuch-VDLUFA, 1983-1999); content of crude ash was determined by combustion at $550^{\circ} \mathrm{C}$.

\section{Totalphenol analyses}

The total content of phenolic compounds was determined using the spectrophotometric method. An analytical reaction was a positive reaction of Berlin blue solution, which was obtained from a mixture of ferrous iron and potassium hexacyanoferrate $\left(\mathrm{K}_{3} \mathrm{Fe}(\mathrm{CN})_{6}\right)$. The content of phenolic compounds was calculated based on light absorbance of the obtained solution at the wavelength $720 \mathrm{~nm}$. The solutions of gallic acid were used as a standard.

The plant samples were homogenized in acidulated 96-degree ethanol (20:1), the homogenate was centrifuged at $4500 \mathrm{rpm}$ for $30 \mathrm{~min}$ (Gupta and Verma, 2011). The optical density of the solutions was determined using a spectrophotometer "SF-2000" (ZAOOKB Spectr).

\section{Anthocyanin and leucoanthocyanin analyses}

The concentration of the anthocyanin pigments was determined spectrophotometrically in $1 \%$ hydrochloric acid aqueous extract at wavelength $510 \mathrm{~nm}$, after the homogenate was centrifuged at $4500 \mathrm{rpm}$ for $30 \mathrm{~min}$. The content of anthocyanin was calculated based on light absorbance of the obtained solution at the wavelength $657 \mathrm{~nm}$. Anthocyanin content was calculated from the amount of cyanidin-3.5-diglucoside (Chupakhina et al., 2010). The absorption of these pigments was determined using a spectrophotometer "SF-2000" (ZAO "OKB SPECTRUM", Russia). Content of leucoanthocyanin was measured according to Yashin et al. (2007) method.

\section{Soilanalyses}

Soil analyses were conducted at the Laboratory of Food Raw Materials, Agronomic and Zootechnical Research of Aleksandras Stulginskis University. Soil $\mathrm{pH}_{\mathrm{KC}}$ was established by the potentiometric method in $1 \mathrm{~N} \mathrm{KCl} \mathrm{extract.} \mathrm{The} \mathrm{content} \mathrm{of} \mathrm{total}$ nitrogen in the soil was established by the Kjeldahl method. The content of available phosphorus was determined by the CAL method using a spectrophotometer as well available potassium content using a flame photometer.

\section{Statistical analysis}

The experimental data were statistically processed by ANOVA, software STATISTIKA 7.0 (StatSoft, USA). Means and standard deviations of the data were calculated. Tukey's HSD test $(p<0.05)$ was applied to estimate significance of differences. 
394

Table 2. The influence of biodynamic $(\mathrm{BD})$ preparations on some quality indices of tubers of coloured potato cultivars $(\% \mathrm{dm}$.)

\begin{tabular}{|c|c|c|c|}
\hline \multirow{3}{*}{ Treatments } & \multicolumn{3}{|c|}{ Quality indices } \\
\hline & Dry matter & Crude fiber & Crude ash \\
\hline & \multicolumn{3}{|c|}{ 'Red Emmalie' } \\
\hline Control (without BD preparations) & $17.96 \pm 0.69^{b}$ & $2.20 \pm 0.06^{\mathrm{b}}$ & $5.45 \pm 0.19^{b}$ \\
\hline BD preparations 500 & $19.63 \pm 0.71^{\mathrm{a}}$ & $2.47 \pm 0.13^{\mathrm{a}}$ & $6.17 \pm 0.22^{\mathrm{a}}$ \\
\hline BD preparations 501 & $19.80 \pm 0.78^{\mathrm{a}}$ & $2.22 \pm 0.10^{\mathrm{b}}$ & $6.23 \pm 0.23^{\mathrm{a}}$ \\
\hline \multirow[t]{2}{*}{ BD preparation 500 in combination with BD preparation 501} & $18.87 \pm 0.64^{\mathrm{b}}$ & $2.26 \pm 0.09^{\mathrm{ab}}$ & $6.14 \pm 0.25^{\mathrm{a}}$ \\
\hline & \multicolumn{3}{|c|}{ 'Blue Congo' } \\
\hline Control (without BD preparations) & $20.56 \pm 0.73^{\mathrm{a}}$ & $1.99 \pm 0.09^{\mathrm{a}}$ & $4.84 \pm 0.13^{\mathrm{a}}$ \\
\hline BD preparations 500 & $19.33 \pm 0.87^{\mathrm{a}}$ & $2.03 \pm 0.08^{\mathrm{a}}$ & $4.85 \pm 0.11^{\mathrm{a}}$ \\
\hline BD preparations 501 & $19.60 \pm 0.69^{a}$ & $2.15 \pm 0.10^{\mathrm{a}}$ & $5.06 \pm 0.15^{\mathrm{a}}$ \\
\hline \multirow[t]{2}{*}{ BD preparation 500 in combination with BD preparation 501} & $20.63 \pm 0.93^{\mathrm{a}}$ & $2.21 \pm 0.14^{\mathrm{a}}$ & $4.93 \pm 0.17^{\mathrm{a}}$ \\
\hline & \multicolumn{3}{|c|}{ 'Vitelotte' } \\
\hline Control (without BD preparations) & $26.17 \pm 0.93^{\mathrm{a}}$ & $1.85 \pm 0.07^{\mathrm{b}}$ & $4.95 \pm 0.15^{\mathrm{a}}$ \\
\hline BD preparations 500 & $26.27 \pm 0.86^{\mathrm{a}}$ & $2.17 \pm 0.13^{\mathrm{a}}$ & $5.25 \pm 0.16^{\mathrm{a}}$ \\
\hline BD preparations 501 & $26.71 \pm 0.98^{\mathrm{a}}$ & $2.15 \pm 0.15^{\mathrm{a}}$ & $5.29 \pm 0.21^{\mathrm{a}}$ \\
\hline BD preparation 500 in combination with BD preparation 501 & $27.69 \pm 1.09^{\mathrm{a}}$ & $2.20 \pm 0.08^{\mathrm{a}}$ & $5.11 \pm 0.17^{\mathrm{a}}$ \\
\hline
\end{tabular}

Note: Mean values \pm standard deviation $(\mathrm{x} \pm \mathrm{SD})$.

ab - Different letter superscripts in the same column indicate significant differences among samples $(p<0.05)$

Table 3. The influence of biodynamic (BD) preparations on the contents of antioxidant compounds in tubers of coloured potato cultivars

\begin{tabular}{|c|c|c|c|}
\hline \multirow{3}{*}{ Treatments } & \multicolumn{3}{|c|}{ Antioxidant compounds } \\
\hline & $\begin{array}{l}\text { Total phenolics } \\
\text { (mgg } \mathrm{mg}^{-1} \mathrm{~m} \text {.) }\end{array}$ & $\begin{array}{l}\text { Total anthocyanins } \\
\left.\text { (mg } 100 \mathrm{~g}^{-1} \mathrm{~d} . \mathrm{m} .\right)\end{array}$ & 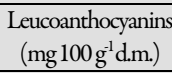 \\
\hline & \multicolumn{3}{|c|}{ 'RedEmmalie' } \\
\hline Control (without BD preparations) & $2.37 \pm 0.07^{\mathrm{b}}$ & $0.91 \pm 0.02^{\mathrm{d}}$ & $85.55 \pm 2.99^{\mathrm{bc}}$ \\
\hline $\mathrm{BD}$ preparations 500 & $1.98 \pm 0.06^{c}$ & $1.36 \pm 0.05^{\mathrm{b}}$ & $87.68 \pm 2.45^{b}$ \\
\hline BD preparations 501 & $2.59 \pm 0.07^{\mathrm{a}}$ & $1.19 \pm 0.03^{c}$ & $82.90 \pm 2.26^{c}$ \\
\hline \multirow[t]{2}{*}{$\mathrm{BD}$ preparation 500 in combination with $\mathrm{BD}$ preparation 501} & $2.69 \pm 0.08^{a}$ & $1.52 \pm 0.06^{\mathrm{a}}$ & $93.54 \pm 3.11^{\mathrm{a}}$ \\
\hline & \multicolumn{3}{|c|}{ 'Blue Congo' } \\
\hline Control (without BD preparations) & $2.44 \pm 0.09^{\mathrm{b}}$ & $0.98 \pm 0.05^{\mathrm{b}}$ & $28.47 \pm 1.03^{c}$ \\
\hline BD preparations 500 & $1.53 \pm 0.10^{c}$ & $1.00 \pm 0.04^{\mathrm{b}}$ & $39.58 \pm 1.41^{\mathrm{b}}$ \\
\hline BD preparations 501 & $3.17 \pm 0.15^{\mathrm{a}}$ & $1.00 \pm 0.05^{\mathrm{b}}$ & $43.65 \pm 1.68^{\mathrm{a}}$ \\
\hline \multirow[t]{2}{*}{$\mathrm{BD}$ preparation 500 in combination with $\mathrm{BD}$ preparation 501} & $2.95 \pm 0.11^{\mathrm{a}}$ & $1.17 \pm 0.08^{\mathrm{a}}$ & $46.51 \pm 1.56^{\mathrm{a}}$ \\
\hline & \multicolumn{3}{|c|}{ 'Vitelotte' } \\
\hline Control (without BD preparations) & $8.42 \pm 0.10^{b}$ & $5.39 \pm 0.09^{c}$ & $297.60 \pm 5.71^{\mathrm{ab}}$ \\
\hline $\mathrm{BD}$ preparations 500 & $7.76 \pm 0.09^{c}$ & $6.53 \pm 0.13^{\mathrm{a}}$ & $289.74 \pm 5.43^{\mathrm{b}}$ \\
\hline BD preparations 501 & $8.64 \pm 0.08^{a}$ & $6.23 \pm 0.11^{b}$ & $288.69 \pm 6.02^{\mathrm{b}}$ \\
\hline $\mathrm{BD}$ preparation 500 in combination with $\mathrm{BD}$ preparation 501 & $8.66 \pm 0.10^{\mathrm{a}}$ & $6.59 \pm 0.16^{\mathrm{a}}$ & $308.95 \pm 6.53^{\mathrm{a}}$ \\
\hline
\end{tabular}

Note: Mean values \pm standard deviation $(\mathrm{x} \pm \mathrm{SD})$.

abcd - Different letter superscripts in the same column indicate significant differences among samples $(p<0.05)$

\section{Results}

\section{Drymattercontent}

The content of dry matter in potato tubers is one of the main indices of quality in determining the processing ability of the product. According to Hassanpanah et al. (2011) the content of dry matter in potato tubers can fluctuate from 13.1 to $36.8 \%$ with an average of $24 \%$. In the present study we found that, in comparison with the control, separately used BD preparations 500 and 501 substantially increased content of dry matter in 'Red Emmalie' tubers. However, separately and in combination used BD preparations did not affect the content of these substances in tubers of 'Blue Congo' and 'Vitelotte' (Table 2). Kjellenberg and Grandstedt (2005) after 33 years of research concluded that using of biodynamic preparations had positive influence on the accumulation of dry matter in cereal.

The highest content of dry matter was observed in 'Vitelotte' tubers when treated with $\mathrm{BD}$ preparation 500 in combination with BD preparation 501 (27.69\%). The lowest dry matter content was recorded for the control (17.96\%) in the case of 'Red Emmalie' tubers (Table2).

\section{Crudefibre content}

Another important component of potato tubers is dietary fibre, which consists of cellulose, hemicelluloses, pectins and lignin, as well as other substances resistant to digestive enzymes (Mazurczyk, 2005). Accumulation of crude fibre is a heritable character, but is also affected by a number of environmental factors. The study revealed that BD preparations 500 and 501 used separately or in combination had unequal impact on the content of crude fibre in tubers of the cultivars tested. The content of these compounds in 'Vitelotte' tubers was found essentially higher for all biodynamic treatments compared with the control. Also, separately application of BD preparation 500 increased the content of crude fibre in 'Red Emmalie' tubers (Table 2). Langenkämper et al. (2006) studied the content of ash and fibre in wheat grown in different farming systems (organic, biodynamic and intensive). However, no essential differences of the content of crude fiber were found.

Crude fibre content varied insignificantly among potato cultivars from $1.85 \%$ (for 'Vitelotte', when cultivated without BD preparations) to $2.47 \%$ (for 'Red Emmalie', when cultivated with BD preparation 500) (Table2). 


\section{Crude ash content}

According to literature data, mean content of crude ash in potato tubers is $4.41 \%$ (Lister and Munro, 2000). We found that BD preparations 500 and 501 used separately or in combination had significally influenced the content of crude ash only in potato tubers of 'Red Emmalie' (Table 2). The application of BD preparations 500 and 501 had no significant effect on the content of crude ash in tubers of 'Vitelotte' and 'Blue Congo'. The crude ash content in the cultivars ranged from $4.84 \%$ to $6.23 \%$. The highest content $(6.23 \%)$ showed 'Red Emmalie' tubers when the plants were cultivated with BD preparation 501 . The least content $(4.84 \%)$ was observed in tubers of 'Blue Congo' when the plants were cultivated without BD preparations (control treatment) (Table 2).

\section{Totalphenolic content}

Navarre et al. (2011) reported that coloured potatoes showed high variability in total phenolic content, ranging from 1.8 to 11.0 $\mathrm{mgg}^{-1} \mathrm{~d} . \mathrm{m}$. The present study revealed that $\mathrm{BD}$ preparations 500 and 501 used separately or in combination had unequal impact on the content of total phenolics for all potato cultivars. Separately used BD preparation 501 and combination of BD preparations 500 and 501 significantly increased the content of total phenolics in tubers of all cultivars (Table 3).

There are some reports in literature that optimization of nutrition with silicon increases the phenolic compounds and stress enzymes in plant tissues (Sivanesan and Park, 2014). However, separately used BD preparation 500 decreased the content of these compounds in tubers of all cultivars (Table 3 ). It could be associated with a greater impact of this treatment on the preparation of vegetative parts of the plant growth and root system development (Spaccini et al. 2012). Maciel et al. (2011) found that the biodynamically grown mangoes showed the highest content of phenolic compounds. In another study on effect of BD preparations on grape quality, Reeve et al. (2005) generally found no differences and only in one year of their research the content of total phenolics and anthocyanins in biodynamically-cultivated grapes was higher.

We found that the highest total phenolics content was characteristics for the tubers of 'Vitelotte' when cultivated with combination of BD preparations 500 and 501 (8.66 $\mathrm{mg} \mathrm{g}^{-1} \mathrm{~d} . \mathrm{m}$.), while the lowest for the tubers of 'Blue Congo' when cultivated with BD preparation 500 (1.53 $\mathrm{mg} \mathrm{g}^{-1} \mathrm{~d} . \mathrm{m}$.). 'Vitelotte' tubers had significally higher content of total phenolics than 'Blue Congo' and 'Red Emmalie' (Table 3). This can be explained by a more intense flesh colour of 'Vitelotte' tubers. According to literature, dark blue- or purple-fleshed potatoes show higher total phenolic content compared to light blue- or purple and red-fleshed ones (Jansen and Flamme, 2006; Reddivari et al., 2007).

\section{Totalanthocyaninscontent}

Anthocyanins (classified as flavonoids) are secondary plant metabolites responsible for blue, purple or red hues in vegetables and fruits. Low content of anthocyanins in yellow- and white-flesh potato cultivars was reported, but they are the main source of antioxidants in purple and red cultivars (Andre et al., 2009).

The current results showed that treatment with $\mathrm{BD}$ preparations 500 in combination with $\mathrm{BD}$ preparation 501 significantly influenced accumulation of anthocyanins in tubers of all cultivars compared to the control ones (Table 3). These pigments content increased 1.7 times in 'Red Emmalie' and 1.2 times in 'Blue Congo' and 'Vitelotte' tubers. Separately used BD preparations 500 and 501 essentially increased the content of total antocyanins only in 'Red Emmalie' and 'Vitelotte' tubers (Table 3). Heimler et al. (2012) studied the effect of BD preparations on 'Batavia' lettuce quality, and also established that the total anthocyanins content was higher in plants from biodynamic farming. According to the authors, the reason may be associated with stress conditions in biodynamic farming or to different microbial environment.

It was also observed that 'Vitelotte' tubers accumulated the highest amount of total anthocyanins in treatment with

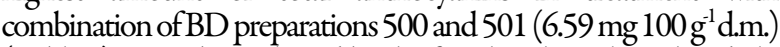
(Table 3). It can be explained by the fact that this cultivar has darkpurple flesh practically in the entire cross-section. The lowest amount of these compounds was determined in 'Red Emmalie' tubers $\left(0.91 \mathrm{mg} 100 \mathrm{~g}^{-1}\right.$ d.m.) when the plants were cultivated without BD preparations (Table 3). Previous studies on antioxidant compounds in purple-, red-, yellow and white-flesh potatoes also showed that dark-blue or purple-flesh cultivars contained significantly more anthocyanins than other cultivars (Hamouz et al., 2011; Nayaket al.,2011).

\section{Leucoanthocyanins content}

Potatoes are considered a good source of antioxidants, such as leucoanthocyanins.

These flavonoids help to strengthen blood vessels, increasing the tone and elasticity of capillary walls and help to quench free radicals (Tsao et al., 2006). The BD preparations had different effect on the content of leucoanthocyanins in the cultivars (Table 3). Separately and in combination used BD preparations 500 and 501 substantially increased the content of leucoanthocyanins in 'Blue Congo' tubers. The content of these compounds in tubers of 'Red Emmalie' was higher after treatment with BD preparations 500 in combination with $\mathrm{BD}$ preparation 501 compared to the control. However, BD preparations had no influence on the leucoanthocyanins content in 'Vitelotte' tubers (Table 3).

Basically, the greatest content of all the leucoanthocyanins was established for the biodynamic treatment, when the plants were treated with combination of BD preparations 500 and 501 (308.95 $\mathrm{mg} 100 \mathrm{~g}^{-1} \mathrm{~d} . \mathrm{m}$. for the tubers of 'Vitelotte') and the lowest in the

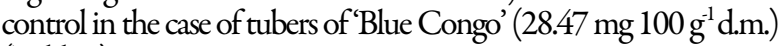
(Table 3).

\section{Conclusion}

BD preparations 500 and 501 had no significant effects on the contents of dry matter, crude fibre and crude ash in tubers of all tested potato cultivars of coloured flesh. However, BD preparation 500 decreased the content of total phenolics in all cultivars, but increased the content of total anthocyanins in tubers of 'Vitelotte' and 'Red Emmalie' and the content of leucoanthocyanins in 'Blue Congo'. BD preparation 501 had significant effect on the content of total phenolics (in all cultivars), total anthocyanins (in 'Vitelotte' and 'Red Emmalie') and leucoanthocyanins (in 'Blue Congo'). Application of BD 500 in combination with BD 501 substantially increased the contents of total phenolics and total anthocyanins in all tested cultivars.

The results revealed that 'Vitelotte' tubers, with dark-purple flesh, contained substantially more total phenolics, total anthocyanins and leucoanthocyanins than the light-purple and red potato cultivars. 
396

\section{References}

Andre CM, Oufir M, Hoffmann L, Hausman JF, Rogez H, Larondelle Y (2009). Influence of environment and genotype on polyphenol compounds and in vitro antioxidant capacity of native Andean potatoes (Solanum tuberosum L.). Journal of Food Composition and Analysis 22(6):517-524.

Brinton WF (1997). Dynamic chemical processes underlying BD horn manure (500) preparation. Journal of Biodynamics 214:1-8.

Catellani G (2006). Guide to biodynamic farming. Association for Biodynamic Agriculture, Milan, 142 p.

Chupakhina GN, Maslennikov PV, Skrypnik LN, Frolov EM (2010). Evaluation of the antioxidant status of plants of different ecological groups of the Curonian Spit. Bulletin of the Immanuel Kant State University of Russia 7:77-83.

Dai J, Mumper RJ (2010). Plant phenolics: extraction, analysis and their antioxidant and anticancer properties. Molecules 15(10):73137352.

Danilcenko H, Jariené E, Vaitkevicienè N, Juknevicienė E, Gajewski M (2014). Great pumpkins and blue fleshed potatoes - biologically active raw material for food products. International Journal of Science and Research 3(4):56-58.

Fritz J, Kopke U (2000). Horn silica application in combination with plant extracts. Proceedings $13^{\text {th }}$ International IFOAM Scientific Conference, Basel, Switzerland 416p.

Gupta Ch, Verma R (2011) Visual estimation and spectrophotometric determination of tannin content and antioxidant activity of three common vegetable. International Journal of Pharmaceutical Sciences and Research 2(1):175-182.

Hamouz K, Lachman J, Pazderů K, Tomášek J, Hejtmánková K, Pivec V (2011). Differences in anthocyanin content and antioxidant activity of potato tubers with different flesh colour. Plant, Soil and Environment 57(10):478-485.

Hassanpanah D, Hassanabadi H, Azizi Chakherchaman SH (2011). Evaluation of cooking quality characteristics of advanced clones and potato cultivars. American Journal of Food Technology 6:72-79.

Heimler D, Vignolini P, Arfaioli P, Isolani L Romani A (2012). Conventional, organic and biodynamic farming: differences in polyphenol content and antioxidant activity of Batavia lettuce. Journal of the Science of Food and Agriculture 92:551-556.

Jansen G, Flamme, W (2006). Coloured potatoes (Solanum tuberosim L.) - anthocyanin content and tuber quality. Genetic Resources and Crop Evolution 53:1321-1331.

Jarienè E, Vaitkevičienė N, Chupakhina N, Poltavskaya RL, Kita A (2013). Antioxidant compounds and antioxidant activity in bluefleshed potatoes. Rural development: The $6^{\text {th }}$ international Scientific Conference Proceedings 6:119-122.

Jayasree P, Annamma G (2006). Do biodynamic practices influence yield, quality and economics of cultivation of chilli (Capsicum annuum L.). International Journal of Tropical Agriculture 44(12):68-70.

Khurana S, Piche M, Hollingsworth A, Venkataraman K (2013). Oxidative stress and cardiovascular health: therapeutic potential of polyphenols. Canadian Journal of Physiology and Pharmacology 91:198-212.

Kjellenberg L, Grandstedt A (2005). The connection between soil, crop and manure - Results of the K-trial - a 33-year study on the effect of fertilisation on the properties of soil and crop. Scandinavian Research Circle for Biodynamic Agriculture, Jarna, Sweden.

Koepf HH, Schaumann W, Haccius M (2001). Biodynamic agriculture. Anthroposophic Press, Hudson NY 366 p.

Lairon D (2010). Nutritional quality and safety of organic food. A review. Agronomy for Sustainable Development 30(1):33-41.

Langenkämper G, Zörb C, Seifert M, Mäder P, FretzdorffB, Betsche T (2006). Nutritional quality of organic and conventional wheat. Journal of Applied Botany and Food Quality 80:150-154.

Leo L, Leone A, Longo C, Lombardi DA, Raimo F, Zacheo G (2008). Antioxidant compounds and antioxidant activity in "early potatoes". Journal of Agricultural and Food Chemistry 56:41544163.

Lister CE, Munro J (2000). Nutrition and health qualities of potatoes - a future focus. Crop \& Food Research Confidential Report No. 143. New Zealand Institute for Crop and Food Res Ltd Christchurch.

LST ISO 751:2000 (2001). Fruit and vegetable products. Determination of water-insoluble solids (idt ISO 751:1998 [E]).

Maciel LF, Oliveira C, Bispo E, Miranda MPS (2011). Antioxidant activity, total phenolic compounds and flavonoids of mangoes coming from biodynamic, organic and conventional cultivations in three maturation stages. British Food Journal 113(9):1103-1113.

Mazurczyk W (2005). Wartość żywieniowa ziemniaka [Nutritional value of potato]. Raport Roln 2(43):48-49 [in Polish].

Methodenbuch-VDLUFA (1983-1999). Band III. Die chemische Untersuchung von Futtermitteln [The chemical analyses of feedstuffs]. Verlag-Darmstadt, Germany [in German].

Navarre DA, Pillai SS, Shakya R, Holden MJ (2011). HPLC profiling of phenolics in diverse potato genotypes. Food Chemistry 127:3441.

Nayak B, Berrios JJ, Powers JR, Tang J, Ji $\quad$ Y(2011). Colored potatoes (Solanum tuberosum L.) dried for antioxidantrich value-added foods. Journal of Food Processing and Preservation 35(5):571-580.

Pęksa A, Kita A, Kułakowska K, Aniołowska M, Hamouz K, Nemś A (2013). The quality of protein of coloured fleshed potatoes. Food Chemistry 141(3):2960-2966.

Raupp J (1999) Biodynamic approaches in research and development. In: Zanoli R, Krell R (Eds). Research Methodologies in Organic Farming. FAO, Rome (Italy). Regional Office for Europe $58 \mathrm{p}$.

Ražukas A (2003). Potatoes biology, breeding, seed production. Vilnius, $166 \mathrm{p}$.

Reddivari L, Hale A, Miller J (2007). Determination of phenolic content, composition and their contribution to antioxidant activity in specialty potato selections. American Journal of Potato Research $84(4): 275-282$.

Reeve JR, Carpenter-Boggs L, Reganold JP, York AL, McGourthy G, McCloskey LP (2005). Soil and winegrape quality in biodynamically and organically managed vineyards. American 
Journal of Enology and Viticulture 56:367-376.

Reganold JP (1995). Soil quality and profitability of biodynamic and conventional farming systems: A review. American Journal of Alternative Agriculture 10:36-44.

Sivanesan I, Park SW (2014). The role of silicon in plant tissue culture. Frontiers in Plant Science 5:571. doi: 10.3389/fpls.2014.00571.

Spaccini R, Mazzei P, Squartini A, Giannattasio M, Piccolo A (2012). Molecular properties of a fermented manure preparation used as a field spray in biodynamic agriculture. Environmental Science and Pollution Research 19:4214-4225.

Teow CC, Truong VD, McFeeters RF, Thompson RL, Pecota KV, Yencho GC (2007). Antioxidant activities, phenolic and $\beta$ carotene contents of sweet potato genotypes with varying flesh colours. Food Chemistry 103:829-838.
Tsao R, Khanizadeh S, Dale A (2006). Designer fruits and vegetables with enriched phytochemicals for human health. Canadian Journal of Plant Science 86:773-786.

Yashin AY, Chernousova NI (2007). The amperometric method of measurement of antioxidants in beverages and foods, biological active additives, extracts of medicinal plants. Certificate of attestation. N31-07.

Zaller JG, Köpke U (2004). Effects of traditional and biodynamic farmyard manure amendment on yields, soil chemical, biochemical and biological properties in a long-term field experiment. Biology and Fertility of Soils 40:222-229. 